JIEBAR : Journal of Islamic Education: Basic and Applied Research

Vol. 01, Nomor 02, Oktober 2020

P-ISSN: 2723-5807

DOI: https://doi.org/10.33853/jiebar.v1i2

E-ISSN: 2723-5793

https://www.e-journal.stit-islamic-village.ac.id/jiebar

\title{
Concept of Moral Education According to KH. Hasyim Asy'Ari in the Book of Adabul 'Alim Wal-Muta'alim
}

\section{Konsep Pendidikan Akhlak Menurut KH. Hasyim Asy’Ari dalam Kitab Adabul 'Alim Wal-Muta'alim}

\author{
Siti Rohmah \\ Program Studi Pendidikan Agama Islam, STIT Islamic Village Tangerang \\ Email: sitirohmah@gmail.com
}

Received: September, 2020.

Published: Oktober, 2020.

Accepted: September, 2020.

\begin{abstract}
The purpose of this research is to find out and study the concept of moral education according to KH. Hasyim Asyari in the book adabul alim wal muta'allim. This research is a study of character studies or individual biographical research which is a type of qualitative research with a textual approach. Data sources are relevant reference books following the issues discussed, Al-Qur'an and hadiths, especially KH. Hasyim Asy'ari in the book adabul 'alim wal muta'allim. The data analysis technique uses deductive and inductive methods. This research shows that the concept of moral education according to $\mathrm{KH}$ Hasyim Asy'ari is very much needed in the world of education, which can then be accustomed to running it within the scope of family, school, relationships, and social society. Characteristics of KH. Hasyim Asy'ari in the book is guided by the Qur'an and the Hadith. KH. Hasyim Asy'ari, which emphasizes ethical values that have Sufistic breath. Moral Education which he emphasized, namely: morals to God and morals to fellow human beings. His concept made the development of a society of religious morality with individual coaching. With the aim that is expected to be able to realize a society of good character, noble and noble character.
\end{abstract}

Keywords: Moral Education, KH Hasyim Asy’ari

\section{ABSTRAK}

Tujuan penelitian ini untuk mengetahui dan mengkaji konsep pendidikan akblak menurut KH. Hasyim Asy'ari dalam kitab adabul 'alim wal muta'allim. Penelitian ini adalah penelitian studi tokoh, atau penelitian riwayat bidup individu yang merupakan jenis 
penelitian kualitatif dengan pendekatan tekstual. Sumber data yaitu buku-buku rujukan yang relavan sesuai dengan masalah yang dibahas, Al-Qur'an dan hadis juga terutama karya KH. Hasyim Asy'ari dalam kitab adabul 'alim wal muta'allim. Adapun teknik. analisis data menggunakan metode deduktif dan induktif. Penelitian ini menunjukkan babwa konsep pendidikan akblak menurut KH Hasyim Asy'ari sangat dibutubkan dalam dunia pendidikan, yang kemudian dapat dibiasakan untuk menjalankannya dalam lingkupan keluarga, sekolah, pergaulan maupun sosial kemasyarakatan. Karakteristike pemikiran KH. Hasyim Asy'ari dalam kitab tersebut berpedoman pada Al-Qur'an dan hadis. Pemikiran KH. Hasyim Asy'ari yaitu mengetengahkan nilai-nilai etis yang bernafaskan sufistik. Pendidikan Akblak yang ditekankan beliau yaitu: akblak kepada Allah dan akblak kepada sesama manusia. Konsep beliau membuat pembangunan masyarakat yang berakblak religius dengan pembinaan individu. Dengan tujuan yang diharapkan bisa mewrijudkan tatanan masyarakat yang berakblak baik, mulia dan berbudi pekerti lubur.

Kata Kunci: Pendidikan Akblak, KH Hasyim Asy'ari

\section{PENDAHULUAN}

Pada akhir abad ke 21 ini secara jelas timbul dampak yang banyak sehingga munculnya fenomena disruptive inovation yang yang menyebar kepada seluruh kehidupan seperti bidang industri, ekonomi, pendidikan dan politik serta berdampak juga kepada bergesernya gaya hidup dan mindset masyarakat di seluruh dunia (Priatmoko, 2018:230). Contohya, segala kehidupan yang ada sekarang ini hampir tergantikan oleh mesin, seperti check barang sudah dilakukan oleh mesin, pemindai visa juga sudah menggunakan mesin. Dari dua contoh tersebut dapat dikatakan bahwa mesin sudah menjadi bagian pada kehidupan manusia.

Percepatan akses teknologi serta kemudahan berinteraksi menjadikan seolah dunia semakin kecil, seperti di dalam genggaman manusia, dalam perkembangan digitalisasi sudah tercabut dari akar aktivitas manusia, kini mesin bukan sebagai penggerak ekonomi saja namun sudah masuk ke sektor ilmu pengetahuan dibidang pendidikan. Hal ini perlu adanya perumusan yang lebih serius mengenai badan organisasi, mata pelajaran, perangkat dan bahan ajar, serta kesiapan untuk pengembangan yang lebih menginovasi pembelajaran (Maemunah, 2018:3).

JIEBAR : Journal of Islamic Education: Basic and Applied Research

Vol. 01, Nomor 02, Oktober2020 
Seluruh stakeholder yang dapat berpengaruh dalam lingkungan seperti orang tua, peserta didik, pendidik, pengawas pendidikan dan masyarakat, kiranya harus mendapatkan berita tentang peningkatan atau penurunan sistem pendidikan di negaranya dalam mempersiapkan peserta didik agar mampu bersaing di abad ke 21 (Syamsuar \& Reflianto, 2019:3). Memang ini bukan tugas yang kecil dalam menentukan arah keberhasilan, tentu setiap orang harus ada campur tangan dari orang lain. Mustahil jika seseorang dapat sukses dan berhasil dengan sedirinya untuk mencapai tujuan yang ingin didapatkan.

Orang tua tentunya dituntut untuk dapat menselaraskan cara mendidik anak dengan perkembangan zaman masa kini sesuai dengan kebutuhannya. Dengan memahami bagaimana konsep dan tujuan pendidikan yang ada serta kebutuhan akan manusia yang ahli dalam bidang teknologi pada sektor manapun (Syamsuar \& Reflianto, 2019:3). Perubahan yang terjadi pada masa kini sangat berpengaruh terhadap kepribadian manusia serta atau tidaknya seseorang dapat belajar dengan sangat cepat mengenai perubahan-perubahan tersebut. Ini menjadi sebuah tantangan yang perlu dihadapi bagi orang tua sebagai modal pendidikan utama untuk menciptakan generasi yang benarbenar siap kerja dan ahli pada bidangnya dalam memanfaatkan kecanggihan teknologi dan informasi (Syamsuar \& Reflianto, 2019:4).

\section{METODE PENELITIAN}

Penelitian ini merupakan penelitian kepustakaan atau kajian literatur (library research), dengan metode pendekatan tematik sebagai pendekatan dalam pengumpulan dan pembahasan datanya. Sedangkan teknis analisis data yang digunakan adalah analisis isi (content analysis), yaitu teknis penelitian yang digunakan untuk menganalisa makna yang terkandung di dalam data yang dihimpun melalui riset kepustakaan.

\section{HASIL DAN PEMBAHASAN}

\section{A. Kiprah KH. Hasyim Asy'ari dalam Pendidikan}

Sebagai pendidik agama Islam, beliau bukan saja sebagai pendidik tetapi juga sebagai panutan sebab keilmuannya. Beliau dihormati oleh berbagai 
kalangan, baik dari kalangan santri, sesama kiai maupun pihak lawan yaitu belanda yang saat itu sedang berkuasa, beliau dapat dikatakan sangat berhasil sebagai seorang pendidik karena kepemimpinannya. Bahkan sampai saat ini pengaruhnya sangat besar baik terhadap pemerintahan, masyarakat maupun para cendekiawan.

Sebagai ulama orang yang berpendidikan tinggi dalam bidang agama, beliau sangat patuh terhadap ajaran agama, giat menyebarkannya kepada sesama ummat, disamping berjuang sebagai penerang bagi masyarakat. Sebagai organisasi massa yaitu Nahdlatul Ulama pada tahun 1926 yang sampai saat ini tercatat sebagai organisasi terbesar di dunia. Sebagai tokoh masyarakat beliau berpedoman pada "Uswatun Hasanah" beliau sangat mengutamakan keteladanan dan kepemimpinana Rasulullah yang sangat mempengaruhi cara beliau memimpin ummat (A'dlom, 2014).

\section{B. Konsep Pendidikan Akhlak Menurut KH. Hasyim Asy'ari dalam Kitab Adabul 'Alim Wal Muta'allim}

Sumber pendidikan sepanjang zaman ialah Rasulullah SAW. Pendidikan tidak akan sukses melainkan dengan contoh dan teladan yang baik. Berbicara tentang pendidikan akhlak KH. Hasyim Asy'ari membuat sebuah kitab yaitu kitab adabul 'alim wal muta'allim. Karakteristik pemikiran KH. Hasyim Asy'ari dalam kitab tersebut berpedoman pada Al-Qur'an dan Hadits. Pemikiran KH. Hasyim Asy'ari adalah mengetengahkan nilai-nilai etis yang bernafaskan sufistik. Keinginan tersebut dibawa melalui gagasan sebuah menuntut ilmu. Menurut beliau ilmu itu bisa dapat diraih jika hatinya bersih dan niat ikhlas dalam mencari ilmu dan tidak mencari aspek keduniaan (Haziq, n.d.).

Dituangkan dalam kitab adabul 'alim wal muta'allim yang membahas tentang akhlak peserta didik dan pendidik dalam meraih ilmu, dan dapat dianalisis pembahasannya, yaitu:

\section{Niat Ikhlas}

Ikhlas dalam Bahasa Arab berasal dari kata Khalasha artinya jenih atau murni. Jadi ikhlas adalah memurnikan rasa dengan mengharapkan ridha Allah SWT., didalam bahasa popolernya ikhlas yaitu melakukan suatu 
perbuatan tidak dengan keinginan untuk memperoleh sesuatu, sematamata hanya untuk mengharapkan ridha Allah SWT (Ilyas, 2014).

Niat merupakan bagian dari pokok setiap aktivitas dalam hal baikburuk, oleh karena itu, semua aktivitas sangat bergantung pada niat. Dapat diketahui, bahwa memperoleh pahala sempurna dari tiap-tiap niat ikhlas, itulah pahala bagi ia yang melakukannya (Al-Husaini, 1999)

Jadi seorang peserta didik dan seorang pendidik harus senantiasa membersihkan niat dalam meraih ilmu, dan dapat mengamalkannya. Memperbanyak beramal kepada Allah untuk menghiasi hati, dan dapat menghidupkan syariat. Allah SWT., berfirman :

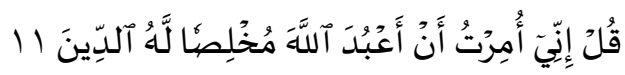

Katakanlah: "Sesunggubnya aku diperintabkan supaya menyembah Allab dengan memurnikan ketaatan kepada-Nya dalam (menjalankan) agama". (Q.S Az-Zumar : 11)

Ayat di atas memerintahkan kepada kita untuk mendukung segala kegiatan dengan ke ikhlasan. Orang yang memiliki niat ikhlas adalah orang yang ingin memurnikan tujuannya untuk taqarrub kepada Allah SWT (Hawa, 2004b).

Seorang pendidik dan peserta didik janganlah berniat menuntut ilmu dengan tujuan untuk meraih duniawi. Karena setiap amal yang didasari dengan hawa napsu tidak dengan niat yang ikhlas karena Allah SWT., akan dapat menyebabkan keruhnya amal itu sendiri.

\section{Berperilaku Qana'ah}

Qona'ah adalah menerima dengan lapang dada. Qona'ah memiliki lima makna yaitu: 1) Menerima keadaan hidup apa adanya. 2) Memohon pada Allah untuk diberikan kecukupan dan berusaha menerima dengan baik dalam hidup. 3. Sabar dalam menerima ketetapan dari Allah SWT. 4. Selalu serah diri kepada Allah SWT. 5. Menghindari tipu muslihat dunia. Makna qona'ah itulah yang menjadi kekuasaan sesungguhnya. Rasulullah SAW bersabda: 
Artiya: "qona'ah itu adalab harta yang tidak akan bilang dan pura (simpanan) yang tidak akan lenyap". (diriwayatkan oleh Thabrani dari Jabir)

Memiliki sifat Qona'ah berarti telah menjaga kekayaannya dan tidak menjalar atau tidak berpindah kepada yang lain (Hamka, 2000). Pendidik dan peserta didik harus senantiasa berperilaku qana'ah dalam semua pandangan hidup. Menerima semua yang telah oleh Allah, maka akhlak ini dapat menjadikan mudah dalam pencapaian keluasan sebuah ilmu dan perbuatan, akhlak juga bisa menjaga hati dan pikiran dari sesuatu yang tidak bermanfaat. Maka berperilaku qana'ah akan timbul berbagai macam kebaikan dan hikmah.

\section{Bersikap Khusyu}

Khusyu adalah sikap tidak berpaling dari urusan yang lain. Seorang pendidik harus memiliki sikap ketenangan dalam memberikan dan meraih sebuah ilmu. Mampu membentuk serta mencerdaskan karakter perilaku peserta didik. Seorang pendidik tidak boleh bersikap acuh atau berpilih kasih dalam memberikan nasehat peserta didik, melainkan ia harus senantiasa selalu mengingatkan dan mengarahkan bahwa tujuan dalam mencari ilmu yaitu mendekatkan diri (ber-taqarrub) pada Allah SWT., tidak untuk mengharapkan sebuah kekuasaan, dan berlomba dengan temannya. Sedangkan untuk peserta didik sendiri harus senantiasa memahami tujuan dalam menuntut ilmu untuk menambah khusyu dan taat kepada Allah SWT.

\section{Bersikap Waro'}

Waro' adalah, menghindari atau menjauhi hal-hal yang tidak baik. Berperilaku waro' merupakan sikap menghindari suatu persoalan yang belum tahu penjelasan status hukumnya. Pendidik dan peserta didik harus bersikap waro' terhadap perkara yang masih diragukan. Dengan berakhlak waro' sebuah ilmu akan mudah di dapat ke dalam akal dan hati dari manfaat sebuah ilmu. Mampu menghindari dari segala perkara yang tidak bermanfaat. Dengan demikian bisa memperkuat agama dan menjadi suatu kebiasaan para ulama yang selalu mengamalkan ilmunya. 


\section{Berperilaku Zuhud}

Zuhud adalah mengalihkan sebuah kesenangan dari sesuatu kepada sesuatu yang lebih baik lagi. Tidak meninggalkan maksiat, tidak meninggalkan ketaatan karena kesenangan dunia merupakan tingkatan terendah zuhud, sedangkan tidak sedikit pun menerima dari dunia, kecuali yakin bahwa menerimanya lebih disenangi oleh Allah dari pada menghindarinya itulah tingkat tertinggi zuhud.

Selain derajat zuhud diatas, ditandai tiga hal derajat zuhud yang benar, yaitu tidak menyibukkan diri mencari kesenangan dunia, tidak bangga diri dengan apa yang dimiliki, dan tidak merasa duka apabila kehilangan kekayaan yang dimiliki. (Al-Husaini, Al-Hadad, 1999) Seorang pendidik dan peserta didik juga harus senantiasa membiasakan berperilaku zuhud, karena dapat melindungi diri dari sifat berpoya-poya dan tidak mengingat kesenangan dunia yang akan menghambat dalam mencari ilmu serta berkepribadian akhlak mulia.

\section{Berperilaku Tawadhu}

Tawadhu adalah rendah hati, dan tidak angkuh, tidak menunjukkan diri sendiri atau tidak terlihat berkepala besar. Sikap tawadhu ini harus dapat dimiliki oleh seorang pendidik dan peserta didik. Sebagaimana tawadhu merupakan suatu gambaran perilaku yang ditunjukan oleh Allah SWT., dalam firman-Nya (Q.S Al-Hijr : 88)

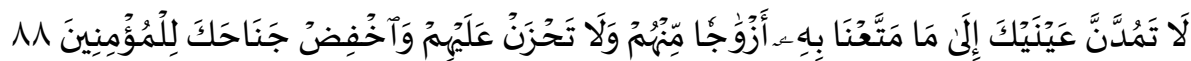

Artinya: 'Janganlah sekali-kali kamu menunjukkan pandanganmu kepada kenikmatan bidup yang telah Kami berikan kepada beberapa golongan di antara mereka (orang-orang kafir itu), dan janganlah kamu bersedih hati terhadap mereka dan berendah dirilah kamu terhadap orang-orang yang beriman"

Jadi setiap peserta didik janganlah menunjukkan atau memperlihatkan kemampuan yang dimilikinya kepada pendidik yang telah mengajarinya, akan tetapi harus menghormati dan mematuhi segala nasihatnya. Peserta didik harus bersikap demikian terhadap pendidik dengan tujuan mengharapkan pahala serta kemuliaan melalui bersikap sopan-santun kepadanya. Dengan berperilaku tawadhu ini mampu bisa mengendalikan 
sikap sombong atau menunjukkan diri terhadap sesama manusia, orang lain yang mempunyai tingkatan ilmu, dan derajatnya.

\section{Berperilaku Kasih Sayang Antar Sesama}

Sifat kasih sayang merupakan sebuah fitrah yang telah dianugerahkan Allah SWT. kepada semua makhluk yang bernyawa, baik manusia ataupun binatang. Seorang pendidik dan peserta didik dalam mencapai suatu tujuan atau mencari ilmu merupakan suatu kewajiban bagi keduanya untuk bersikap saling mengasihi dan menyayangi. Seorang pendidik memberikan ilmu dunia dan akhirat untuk digunakan sebagai tempat diakhirat kelak, tidak hanya didunia saja. Maka dari itu seandainya bukan karena pendidikan dari seorang pendidik, apa yang didapat dari ayahnya akan mendorong pada suatu kehancuran. Sedangkan apa yang diperoleh dari seorang pendidik itulah yang akan menjadi penuntun dalam kehidupan akhiratnya (Al-Baqir, 1996).

Maka dengan berperilaku kasih sayang akan timbul sebuah sifat menghargai, dan ini ditegaskan, menjadi suatu gambaran tingkah laku antar sesama manusia. Berperilaku kasih sayang dan saling menghormati disni seperti: apabila bertemu dengan sesama manusia muslim baik dalam perjalanan, lingkungan sekolah maupun dalam sebuah forum majlis selalu mengucapkan salam, santun dan berakhlak baik.

8. Berperilaku Sabar

Sabar adalah sikap menahan diri dalam emosi atau dalam suatu keinginan. Sabar juga merupakan suatu sikap keutamaan yang sangat dibutuhkan dan harus tertanam dalam diri seorang muslim, baik dalam kehidupan dunia maupun di kehidupan akhiratnya kelak nanti. Ada keterkaitan antara sabar dan syukur, diantaranya yaitu adanya suatu hikmah dan suatu cobaan, yang tidak akan terlepas keduanya di dalam kehidupan manusia. Bersyukur dalam suatu amal perbuatan dapat menumbuhkan dan menuntut adanya sebuah kesabaran dalam diri manusia dalam beramal, maka dari itulah ada tiga gambaran kesabaran, yaitu, sabar akan suatu ketentuan, sabar dari kemaksiatan, dan sabar dalam menghadapi segala masalah dan rintangan hidup. Sabar merupakan bagian dari separuh iman. 
Karena itu tidak satupun maqam iman selain dari kesabaran (Hawa, 2004a). Sebagaimana dalam firman Allah SWT :

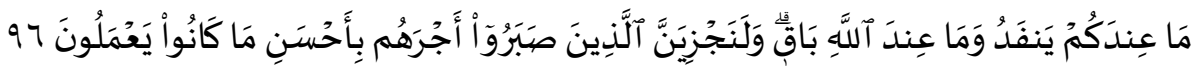

Artinya: "Apa yang di sisimu akan lenyap, dan apa yang ada di sisi Allah adalah kekal. Dan sesungguhnya Kami akan memberi balasan kepada orangorang yang sabar dengan pabala yang lebih baik dari apa yang telab mereka kerjakan”. (Q.S An-Nahl: 96)

Untuk itu, seorang pendidik harus memiliki kesabaran dalam menyampaikan sebuah ilmu, memahami karakter peserta didik agar tetap antusias dalam menerima sebuah pelajaran. Seorang pserta didikpun harus senantiasa sabar dalam menerima sebuah ilmu, sabar terhadap perilaku seorang pendidik dalam suatu proses pembelajaran, dan peserta didik juga harus berfikir positif terhdap hal yang ditujukannya, karena hal ini bertujuan untuk kebaikannya.

9. Memanfaatkan Waktu

Waktu sangat penting untuk manusia, ia harus menyadari kehidupan yang sebenarnya dan juga harus mampu bisa mengoptimalkan waktu yang dimilikinya, baik dalam waktu siang, maupun waktu malam digunakan dan dihabiskan untuk sebagai persiapan menjalani perjalanan yang abadi atau sesungguhnya. Maka dari itu, pergunakanlah waktu untuk selalu belajar baaik belajar ilmu agama mapun ilmu pengetahuan, mengulang-ulang pelajaran yang telah dipelajari, membaca dan menghafal al Quran, dan berdiskusi dalam hal kebaikan. Agar waktu itu dapat digunakan dengan bermanfaat dan tidak terbuang secara percuma.

Pendidik harus senantiasa bisa memperlihatkan perhatiannya dalam setiap disiplin ilmu, agar dapat memahami masing-masing tujuannya. Apabila masih ada kesempatan, maka mulailah dengan mempelajari dan mendalaminya, mengurangi kesibukan yang berkaitan dengan kesibukan duniawi, hal ini akan mencuri perhatian dari tujuan yang akan dicapai.

10. Menghindari Hal-hal yang Kotor dan Maksiat

Seorang pendidik dan peserta didik harus bisa menjauhi dan meninggalkan perbuatan yang kotor dan maksiat, karena ini bisa 
menjatuhkan harga diri serta dapat menghilangkan kejernihan cahaya hati, menghilangkan sebuah kepahaman dan hati tidak dapat dimasukkannya dengan ilmu. Jadi, hati harus dapat dibersihkan dengan menghilangkan tingkah laku perbuatan kotor dan maksiat. Dengan ilmu bisa mendekatkan hati kepada Allah SWT.

\section{Introspeksi Diri}

Muhasabah atau Intropeksi diri adalah suatu tindakan melihat ke dalam pikiran dan perasaan diri sendiri. Dan menjadi keutamaan yang perlu dilakukan oleh manusia sebagaimana telah Allah jelaskan dalam firmanNya:

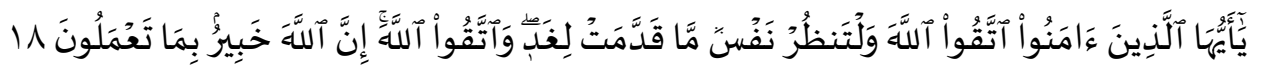

"Hai orang-orang yang beriman, bertakwalah kepada Allah dan hendaklah setiap diri memperbatikan apa yang telah diperbuatnya untuk hari esok (akbirat); dan bertakwalah kepada Allah, sesunggubnya Allah Maha Mengetahui apa yang kamu kerjakan”. (Q.S Al-Hasyr : 18)

Dari penjelasan diatas merupakan bentuk isyarat intropeksi diri terhadap suatu amal perbuatan yang telah dilakukan. Pendidik dan peserta didik harus senantiasa melakukan intropeksi dirinya. Apabila telah melakukan kesalahan, dan telah melakukan suatu perbuatan dosa baik yang disengaja ataupun tidak, maka harus cepat-cepat segera membenahi diri dengan bertaubat, menyesali perbuatan yang telah dikerjakan dan berusaha meninggalkannya.

Membuat suasana religius dengan membiasakan akhlak yang baik dalam setiap kegiatan belajar mengajar menjadikan suatu langkah menuju citacita dalam mengimbangkan dunia dan akhirat, dan bisa membuat pembangunan masyarakat yang religius dengan pembinaan individu. Dengan tujuan yang diharapkan bisa mewujudkan tatanan masyarakat yang berakhlak baik, mulia dan berbudi pekerti luhur.

Dalam kehidupan, menurut KH. Hasyim Asy'ari yaitu berlandaskan Islam yang bersumber pada wahyu al Qur'an dan Hadits dan juga pendekatan diri melalui cara pembersihan jiwa (sufi). Beliau juga memiliki pandangan bahwa suatu keberhasilan dalam proses pebelajaran tidak akan terlepas dari 
pendidikan akhlak. Inilah suatu hasil ciptaan beliau yang terbukti dengan sebuah karangan yang menjelaskan konsep kependidikan, dan dirangkap dalam kitab adabul 'alim wal muta'allim. Proses pembelajaran merupakan suatu proses yang berlangsung dilakukan dengan melibatkan seorang pendidik dan peserta didik (Noor, 2010).

Analisis konsep pendidikan menurut KH. Hasyim Asy'ari dalam kitab adabul 'alim wal muta'allim, penulis mencoba untuk menyatukan isi atau inti etika dari sebuah pendidikan, baik subjek penerima (peserta didik) atau subjek pemberi (pendidik), dan tidak secara terpisah, sesuai harapan agar bisa memudahkan gambaran dari relevansinya dengan dunia pendidikan, terutama sebuah pendidikan di Indonesia.

Kitab adabul 'alim wal muta'allim ini semata-mata dapat memberikan petunjuk yang praktis bagi siapapun yang terlibat dalam sebuah proses pendidikan, sebagaimana dikemukakan oleh KH. Hasyim Asy'ari mengenai sebuah latar belakang penulisannya. Kitab adabul 'alim wal muta'allim ini memiliki persamaan dengan kitab ta'lim al-muta'allim karya Al-Zarnuji. Karakter pendidikan dalam pemikiran KH. Hasyim Asy'ari dapat termasuk kedalam mazhab Syafi'iyyah, dan telah dibuktikan bahwa beliau sering mengumpulkan tokoh-tokoh Syafi'iyyah, khususny tokoh Imam Syafi'i daripada tokoh mazhab lain. Pemikiran KH. Hasyim Asy'ari yaitu mengutarakan nilai-nilai etis yang bersifat sufistik. Dalam memastikan pemikiran KH. Hasyim Asy'ari beliau mengungkapkan bahwa sebuah keutaman ilmu adalah bagi orang yang benar-benar mencari ilmu karena Allah (lillahi).

\section{KESIMPULAN}

Pemikiran pendidikan Islam menurut KH. Hasyim Asy'ari yang tertuang dalam kitab Adabul 'Alim Wal Muta'allim sebagai berikut: Bab pertama, menjelaskan keutamaan ilmu dan ulama dan keistimewaan mengajar dan belajar, bab kedua, menjelaskan akhlak pribadi seorang peserta didik, bab ketiga, menjelaskan akhlak peserta didik kepada pendidik, bab keempat, menjelaskan akhlak peserta didik dalam belajar, bab kelima, menjelaskan akhlak pribadi seorang pendidik, bab keenam, menjelaskan akhlak pendidik 
dalam mengajar, bab ketujuh, menjelaskan akhlak pendidik kepada peserta didiknya, bab kedelapan, menjelakan akhlak kepada buku sebagai sarana ilmu dan sifat-sifat yang berhubungan dengan kepemilikan, penyusunan, dan penulisan buku.

KH. Hasyim Asy'ari menegaskan bahwa pendidikan akhlak yaitu suatu kegiatan yang dilakukan pendidik kepada anak didik dalam upaya membangun nilai-nilai akhlak mulia, baik terhadap sang pencipta Allah SWT., sesama manusia maupun alam sekitar. Adapun nilai-nilai pendidikan akhlak dalam kitab adabul 'alim wal muta'allim perihal akhlak seorang peserta didik dan seorang pendidik dalam meraih ilmu yang harus diterapkan yaitu; Niat Ikhlas. berperilaku Qana'ah, bersikap Khusyu, bersikap Waro', berperilaku Zuhud, berperilaku Tawadhu, berperilaku kasih sayang antar sesama, berperilaku Sabar, memanfaatkan waktu, menghindari hal-hal yang kotor dan maksiat, intropeksi diri.

\section{REFERENSI}

A'dlom, S. (2014). Kiprah Kh, Hasyim Asy'ari dalam Mengembangkan Pendidikan Agama Islam". Jurnal Pustaka.

Al-Abrasyi, M. A. (1990). Dasar-dasar Pokok Pendidikan Islam. Terjemahan Bustami A Gani dan Djohar Bahry. Jakarta: Bulan Bintang.

Al-Baqir, M. (1996). Al-'Tlm. Bandung: Karisma.

Al-Husaini, Al-Hadad, A. bin A. (1999). Risalah Al-Mu'awanah wa AlMuwazhaharah wa Al-Muwazarah Li Ar-Rhaghibin min Al-Mu'minin: Fi Suluk Thariq Al-Akhirah. Terjemah oleh Anwar, Rosihon dan Maman Abd. Djaliel. Bandung: Pustaka Setia.

Amin, A. (1975). Akhlak, terj. Farid Ma'ruf , Ethika, (Ilmu Akhlak). Jakarta: Bulan Bintang.

Anis, I. (1972). Al Mu“jam Al Wasith. Mesir: Darul Ma’arif.

Asy'ari, T. D. M. A. H. (2016). Pendidikan Akhlak untuk Pengajar dan Pelajar, Terjemah Kitab Adabul 'Alim wal Muta'allim) Karya KH. M. Hasyim Asy'ari. Jawa Timur: Pustaka Tebuireng. 
Dhofier, Z. syari. (1982). Tradisi Pesantren, studi tentang pandangan hidup kyai. Jakarta: LP3ES.

Hadikusumo, K. (1996). Pengantar Pendidikan. Semarang: IKIP Semarang Pers.

Halim, A. (2002). Pendidikan Islam: Pendekatan Historis, Teoris dan Praktis. Jakarta: Ciputat Pers.

Hamka. (2000). Tasauf Modern. Jakarta: Pustaka Panjimas.

Hawa, D. S. bin M. (2004b). Al-Mustakhlash fii Tazkiyatil Anfus. Terjemah oleh Tamhid, Aunur Rafiq Shaleh. Jakarta: Robbani Press.

Haziq, M. I. (n.d.). Adab al-Alim wa al-Muta"allim. Jombang: maktabah AtTurats Al-Islamy.

Ilyas, Yunahar. (2014). Kuliah Akhlak (Cet Ke- XII)Kuliah Akhlak (Cet KeXII). Yogyakarta: Lembaga Pengkajian dan Pengalaman Islam LPPI.

Irham, M. (2013). Psikologi Pendidikan: Teori dan Aplikasi dalam Proses Pembelajaran. Yogyakarta: Ar-Ruzz Media.

Kesuma, D. (2011). Karakter (Kajian Teori dan Praktik Disekolah). Bandung: PT Remaja Rosdakarya.

Kholiq Abdul, D. (1999). Pemikiran Pendidikan Islam Kajian Tokoh Klasik dan Kontemporer. Yogyakarta: Pustaka Pelajar.

Khuluq. (2000a). Fajar Kebangunan Ulama Biografi KH. Hasyim Asy'ari. Yogyakarta: LkiS.

Misrawi, Z. (2010a). Hadratussyaikh Hasyim Asy'ari, Moderasi, Keumatan, dan kebangsaan,. Jakarta: Kompas.

Mujib, A., \& Mudzakkir, J. (2010). Ilmu Pendidikan Islam. Jakarta: Kencana Prenada Media.

Muslich, M. (2013). Pendidikan Karakter (Menjawab Tantangan Krisis Multidimensional). Jakarta: Bumi Aksara.

Nata, A. (2010). Ilmu Pendidikan Islam. Jakarta: Kencana. 
Noor, R. M. (2010). K.H. Hasyim Asy'ari; Memodernisasi NU dan Pendidikan Islam. Jakarta: Grafindo Khasanah Ilmu.

Rahman, M. (2001). Pendidikan Islam dalam Perspektif Alquran. Yogyakarta: Pustaka Pelajar.

RI, D. A. (2000). Al-Quran Karim dan Terjemahannya. Bandung: CV Penerbit Diponegoro.

Sukanto. (1994). Paket Moral Islam Menahan Nafsu dari Hawa. Solo: Maulana Offset, cet. I.

Ya'qub, H. (1993). Etika Islam Pembinaan Akhlakul Karimah. Bandung: Diponegoro.

Zuhri, A. M. (2010a). Pemikiran KH. M. Hasyim Asy'ari tentang Ahl al-Sunnah wa al-Jama'ah,. Surabaya: Khalisa. 